\title{
Correlation between geography and cytogenetic diversity in Pomegranate (Punica granatum L.) cultivars in Iran
}

\author{
Masoud Sheidai ${ }^{1,3}$, Sakineh Kolahizadeh ${ }^{2}$, Zahra Noormohammadi ${ }^{2}$, Nasim Azani ${ }^{1}$ and Mehrnoosh Nikoo
}

Recebido em 6/01/2012. Aceito em 25/07/2012

\begin{abstract}
RESUMO
(Correlação entre a distribuição geográfica e diversidade citogenética de cultivares de romã (Punica granatum L.) no Irã). A romã (Punica granatum L.) é uma planta hortícola importante com diversas formas de cultura plantadas em diferentes regiões do Irã. Devido à sua importância econômica, alguns estudos genéticos têm sido realizados para ilustrar a diversidade genética em ambos os níveis cromossômico e molecular em diferentes cultivares de romã que crescem neste país. O presente estudo considera as análises de pareamento cromossômico e cromossomo-B em 21 cultivares de romã e tenta investigar os efeitos dos parâmetros geográficos, como altitude e longitude, bem como a elevação e a queda de chuva média anual sobre a diversidade citogenética destes cultivares. O teste ANOVA revelou a presença de uma diferença significativa para quiasmas e emparelhamento de cromossomos entre as cultivares, indicando a sua diversidade genética. A correlação positiva e significativa foi observada entre o freqüência total de quiamas de quiasmas terminais, quiasmas intercalares e o número médio de quadrivalentes. Uma correlação positiva foi observada entre a queda da chuva anual e o número médio de bivalentes haste, com correlação negativa significativa com o número de bivalentes anel. A altitude não mostrou qualquer correlação com caracteres citogenéticos estudados, enquanto a altitude apresentou correlação negativa significativa com o número de monovalentes. A longitude mostrou correlação positiva e significativa com o número de bivalentes anel e correlação negativa com o número de univalentes e chismata intercalares. A análise de PCA mostrou que tanto as características geográficas quanto citológicos podem contribuir grandemente na diversidade observada nas cultivares de romã. A ocorrência de células multipolares e grãos de pólen não reduzidos foram observados em alguns dos cultivares.
\end{abstract}

Palavras-chave: Citologia, diversidade geográfica, romã.

\begin{abstract}
(Correlation between geography and cytogenetic diversity in Pomegranate (Punica granatum L.) cultivars in Iran). Pomegranate (Punica granatum L.) is an important horticultural plant with several cultivated forms planted in different regions of Iran. Due to its economic importance, studies have been carried out to illustrate the genetic diversity at the chromosomal and molecular levels in different pomegranate cultivars growing in this region. This study analyzed chromosome pairing and B-chromosomes of 21 pomegranate cultivars and tried to investigate the effects of geographical parameters like altitude and longitude as well as elevation and the mean annual rainfall on cytogenetic diversity of these taxa. An ANOVA test revealed the presence of a significant difference for chiasmata and chromosome pairing among the cultivars, indicating their genetic differences. A positive significant correlation was observed between total chiasma frequency and terminal chiasmata, intercalary chiasmata and the mean number of quadrivalents. A significant positive correlation was observed between annual rainfall and the mean number of rod bivalents, while a significant negative correlation was found for the number of ring bivalents. Altitude did not show any correlation with the cytogenetic characters studied, but showed a significant negative correlation with the number of univalents. Longitude showed significant positive correlation with the number of ring bivalents and a negative correlation with the number of univalents and intercalary chiasmata. PCA analysis showed that both geographical and cytological features contribute greatly in the diversity observed in the pomegranate cultivars. The occurrence of multipolar cells and unreduced pollen grains were observed in some of the cultivars.
\end{abstract}

Key words: Cytology, geographical diversity, pomegranate

${ }^{1}$ Shahid Beheshti University, Faculty of Biological Sciences, Evin, Tehran, Iran

${ }^{2}$ Islamic Azad University, Science and Research Branch, Biology Department, School of Basic Sciences, Poonak, Tehran, Iran

${ }^{3}$ Author for correspondence: msheidai@yahoo.com 


\section{Introduction}

Pomegranate (Punica granatum L.) is an important horticultural plant with several cultivated forms planted in different regions of Iran (see Fig. 1). These cultivars differ in their fruit characteristic, such as size, color, time of ripening, disease resistance, and taste.

Pomegranate is a deciduous shrub, known for its beneficial health effects, associated with valuable derived products rich in polyphenols and organic acids (Gong et al. 2004). Historical evidence suggests that the pomegranate originated in Central Asia (including Iran), Afghanistan, and Caucasia to northern India, and has been cultivated since ancient times throughout the Mediterranean region of Asia, Africa and Europe (Stover \& Mercure 2007).

Due to its economic importance, studies have been carried out to illustrate the genetic diversity at both chromosomal and molecular levels on different pomegranate cultivars growing in Iran. Previous works considered both polyploidy level, the occurrence of B-chromosomes and RAPD molecular diversity in some of the cultivars (Sheidai et al. 2005; Sheidai et al. 2007; Talebi-Baddaf et al. 2003; Sheidai \& Noormohammadi 2005; Sheidai et al. 2005; 2007; 2008). About 700 pomegranate accessions are available in Iran, which were collected in the cities of Saveh and Yazd (Behzadi-Shahrbabaki 1998), but information about their polyploidy level and genetic structure is very limited and needs further investigation. This is further supported by the limited number of reports on pomegranate from other parts of the world (Raman et al. 1971; Gill et al. 1981; Xue et al. 1992). Therefore, the present study analyzed chromosome pairing and B-chromosomes of 21 pomegranate cultivars and tried to investigate the effects of geographical parameters like altitude and longitude as well as elevation and the mean annual rainfall on cytogenetic diversity of these

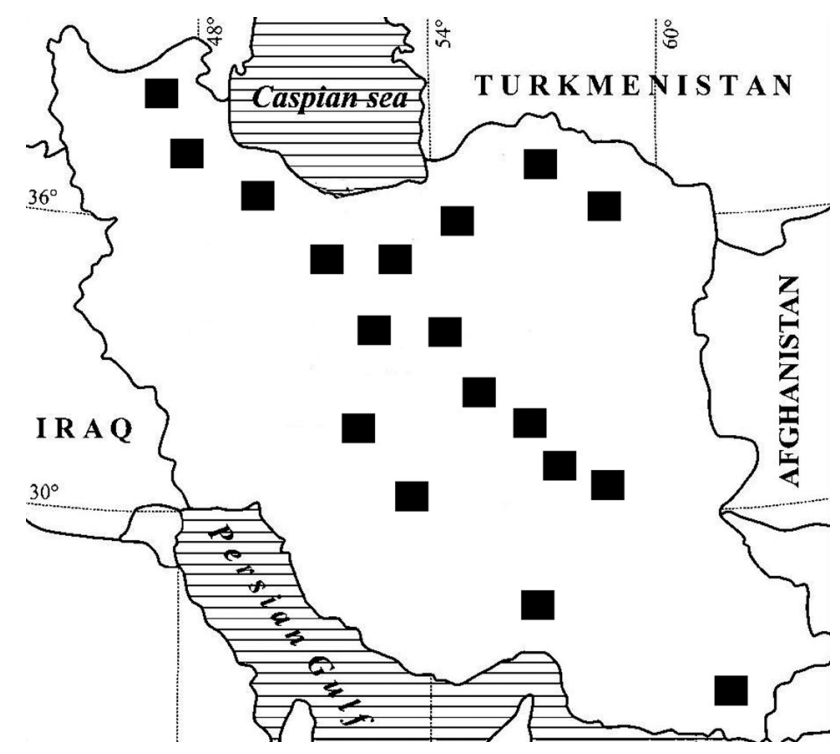

Figure 1. Distribution map of the pomegranate cultivars studied. cultivars. The paper also investigates, for the first time, the role played by ecological and cytological features in genetic diversity of the pomegranate in Iran.

Cultivation of the same cultivars for a long period of time may lead to genetic erosion and confine subsequent breeding programs. Therefore it is necessary to study the available genetic diversity among pomegranate cultivars and to introduce new variability into the plant germplasm.

\section{Material and methods}

Twenty-one Iranian pomegranate cultivars were used for cytological studies (Table 1). Suitable flower buds for cytogenetic studies were collected randomly (from 9-12 a.m.) from 10 randomly selected trees of each cultivar, fixed in glacial acetic acid : ethanol ( $1: 3)$ for $24 \mathrm{~h}$, and then washed thoroughly and transferred to ethanol until use (Sheidai et al. 2005).

Chromosome pairing and chiasma frequency were determined by using a minimum of 100 meiocytes showing diakinesis/metaphase-I stages, while chromosome segregation was studied in a minimum of 500 anaphase I and II stages.

Analysis of variance (ANOVA) followed by the least significant difference test (LSD) was performed on cytogenetic characteristics including chromosome pairing, chiasma frequency as well as distribution to indicate any significant difference among the cultivars studied (Sheidai et al. 2003). Pearson coefficient of correlation was determined between altitude, longitude and the mean annual rainfall with cytogenetic characters studied. Comparison of meiotic data was performed among the cells possessing B-chromosomes and those devoid of Bs by using a $t$-test analysis (Sheidai et al. 2007).

Grouping of the cultivars (those studied here and others reported by us before) was performed by using different clustering methods including UPGMA (Unweighted Paired Group using Average) and WARD (Minimum Spherical Clusters) as well as ordination based on Principal Coordinate Analysis (PCOA). In the multivariate analyses, standardized data $($ mean $=0$, variance $=1$ ) were used. Euclidean and Manhatan distances were used to measure cytological distance among the cultivars (Podani 2000). Cophenetic correlation was determined for different clustering methods.

Principal components analysis (PCA) was performed to identify the important ecological/geographical parameters along with cytological features causing diversity among pomegranate cultivars studied. SPSS ver. 9 (1998) and NTSYS ver. 2.1 (1998) were used for statistical analyses.

Pollen satiability as a measure of fertility was determined by staining a minimum 1000 pollen grains with $2 \%$ acetocarmine: $50 \%$ glycerin (1:1) for about $1 / 2 \mathrm{hr}$. Round, complete pollen grains, which were stained, were considered fertile, while incomplete, shrunken, unstained pollen were considered infertile (Sheidai et al. 2003). 
Table 1. Pomegranate cultivars studied and their geographical details.

\begin{tabular}{|c|c|c|c|c|c|}
\hline Cultivar & Locality & Altitude $(\mathrm{N})$ & Longitude (E) & Rain fall & Elevation \\
\hline Atabaki hafre & Jahrom & $28^{\circ} 29^{\prime} 57^{\prime \prime}$ & $53^{\circ} 33^{\prime} 34^{\prime \prime}$ & 200 & 1383 \\
\hline Malaseaghdaie & Torbateheidarieh & $35^{\circ} 16^{\prime} 26$ & $59^{\circ} 13^{\prime} 10^{\prime \prime}$ & 278.8 & 3300 \\
\hline Bejestoni poostkoloft & Saveh & $35^{\circ} 01^{\prime} 17^{\prime \prime}$ & $50^{\circ} 21^{\prime} 24^{\prime \prime}$ & 80 & 1008 \\
\hline Anbari danehghermez & Kashan & $33^{\circ} 59^{\prime} 20^{\prime \prime}$ & $51^{\circ} 28^{\prime} 38^{\prime \prime}$ & 116.9 & 982 \\
\hline Malasegardan boland & Ashkezar & $31^{\circ} 53^{\prime} 50^{\prime \prime}$ & $54^{\circ} 22^{\prime} 04^{\prime \prime}$ & 61.9 & 1216 \\
\hline Bejestonitorsh & Khazar & $37^{\circ} 27^{\prime} 74^{\prime \prime}$ & $49^{\circ} 58^{\prime} 90^{\prime \prime}$ & 1700 & 0 \\
\hline Dadashipeivandie & Ashkezar & $31^{\circ} 53^{\prime} 50^{\prime \prime}$ & $54^{\circ} 22^{\prime} 04^{\prime \prime}$ & 61.9 & 1216 \\
\hline Goltorsh-mamooli & Taft & $31^{\circ} 44^{\prime} 50^{\prime \prime}$ & $54^{\circ} 12^{\prime} 32^{\prime \prime}$ & 61.9 & 1524 \\
\hline Shirin-poost-nazok & Saveh & $35^{\circ} 01^{\prime} 17^{\prime \prime}$ & $50^{\circ} 21^{\prime} 24^{\prime \prime}$ & 80 & 1008 \\
\hline Shahsavar-torsh & Zanjan & $36^{\circ} 40^{\prime} 30^{\prime \prime}$ & $48^{\circ} 29^{\prime} 04^{\prime \prime}$ & 315.6 & 1663 \\
\hline Malas & Zavareh Ardestan & $33^{\circ} 26^{\prime} 56^{\prime \prime}$ & $52^{\circ} 29^{\prime} 37^{\prime \prime}$ & 121.6 & 2171 \\
\hline Mals-khomreei & Darjazin Semnan & $35^{\circ} 34^{\prime} 22^{\prime \prime}$ & $53^{\circ} 23^{\prime} 50^{\prime \prime}$ & 232 & 1130 \\
\hline Golabihastehdorosht & Sangan & $35^{\circ} 87^{\prime} 32^{\prime \prime}$ & $51^{\circ} 23^{\prime} 56^{\prime \prime}$ & 229.2 & 60 \\
\hline Bazri Morst & Yazd & $31^{\circ} 44^{\prime} 50^{\prime \prime}$ & $54^{\circ} 12^{\prime} 32^{\prime \prime}$ & 61.9 & 1215 \\
\hline Khosh-poostkolft & Shahre-Babak & $30^{\circ} 6^{\prime} 59.4^{\prime \prime}$ & $55^{\circ} 7^{\prime} 7^{\prime \prime}$ & 135 & 1550 \\
\hline Jangli-poostghermez & Rodbar & $36^{\circ} 48^{\prime} 18^{\prime \prime}$ & $49^{\circ} 24^{\prime} 29^{\prime \prime}$ & 1400 & 0 \\
\hline Malas-pishva & Varamin & $35^{\circ} 19^{\prime} 27^{\prime \prime}$ & $51^{\circ} 38^{\prime} 45^{\prime \prime}$ & 400 & 918 \\
\hline Shahsavar-shirin & Yazd & $31^{\circ} 44^{\prime} 50^{\prime \prime}$ & $54^{\circ} 12^{\prime} 32^{\prime \prime}$ & 61.9 & 1215 \\
\hline Malas-poostghermez & Esfahan & $32^{\circ} 39^{\prime} 28^{\prime \prime}$ & $51^{\circ} 40^{\prime} 09^{\prime \prime}$ & 121.6 & 1475 \\
\hline Abdandan & Semnan & $35^{\circ} 34^{\prime} 22^{\prime \prime}$ & $53^{\circ} 23^{\prime} 50^{\prime \prime}$ & 232 & 1130 \\
\hline Malas Nahook & Saravan & $27^{\circ} 22^{\prime} 15^{\prime \prime}$ & $62^{\circ} 20^{\prime} 03^{\prime \prime}$ & 84 & 1142 \\
\hline
\end{tabular}

\section{Results}

The highest value of terminal chiasmata occurred in the cultivar Goltorsh-mamooli Taft (13.27) while the lowest value occurred in Malas poostghermez (10.52). Similarly the highest value of intercalary chiasmata occurred in the cultivar Malase Zavareh (1.86) and the lowest value occurred in Malas Nahook (0.14). The highest and lowest value of total chiasmata occurred in Goltorsh-mamooli Taft and Malas Nahook (14.72 and 10.80 respectively).

The highest amount of ring bivalents occurred in the cultivar Malas-aghdaei Torbateheidarieh (5.41), while the lowest value occurred in Jangli-poostghermez (3.23). The highest value of rod bivalents occurred in Jangli-poostghermez (4.38) and the lowest value occurred in cultivar Goltorsh-mamooli Taft (1.45).

Although Punica granatum is a diploid plant species and is expected to form only bivalents in metaphase I of meiosis, a low value of quadrivalents occurred in the Malas-gardanboland, Bejestonitorsh, Dadashipeivandie, Shirin-poostnazok, Anbari-danehghermez, Shahvar-torsh, Goltorsh-mamooli Taft, Atabaki Jahrom, Malas-aghdaei and Bejestoni-poostkoloft cultivars (Table 1., Fig. 2). Univalents were formed in a low frequency in most of the cultivars studied (Table 1). The highest value was observed in Malas Nahook (2.95) and the lowest value occurred in cultivar Golabi-hastehdorosht (0.11).

ANOVA tests (not presented) revealed the presence of a significant difference $(p<0.01)$ for chiasma frequency and distribution as well as bivalent formation among the cultivars studied. Therefore at least two cultivars differ significantly in their meiotic behavior. The LSD test showed that such significant difference is present in most of the cultivars studied, particularly those cultivars that are placed in different clusters/ groups in the cluster analysis (explained in the following paragraphs).

Coefficient of correlation (Table 2) determined among cytogenetic characters indicates a positive significant correlation between total chiasma frequency and terminal chiasmata $(\mathrm{r}=0.85, \mathrm{p}<0.01)$, intercalary chiasmata $(\mathrm{r}=0.56, \mathrm{p}<0.01)$ and the mean number of quadrivalents $(r=0.75, p<0.01)$. A significant negative correlation was observed between total chiasma frequency and the mean number of rod bivalents $(\mathrm{r}=-0.58, \mathrm{p}<0.01)$ and univalents $(\mathrm{r}=0.61, \mathrm{p}<0.01)$. Pollen fertility ranged from $83.00-99.25 \%$ in the cultivars studied.

A significant positive correlation was observed between annual rainfall and the mean number of rod bivalents, while significant negative correlation was observed for the number of ring bivalents (Table 3). Elevation did not show any correlation with cytogenetic characters studied, while altitude showed significant negative correlation with the number of univalents. Longitude showed a significant positive correlation with the number of ring bivalents and negative correlation with the number of univalents and intercalary chismata (Table 3).

Data concerning chromosome segregation is provided in Table 4. Although in most of the cases normal chromosome 
Table 2. Cytological characteristics in pomegranate cultivars studied.

\begin{tabular}{|c|c|c|c|c|c|c|c|c|c|c|}
\hline Cultivar & $2 n$ & $\mathrm{TX}$ & IX & TOX & $\mathrm{RD}$ & $\mathrm{RB}$ & I & IV & SP1 & SP2 \\
\hline Atabaki-hafre & 16 & 13.21 & 0.27 & 13.48 & 2.39 & 4.85 & 0.19 & 0.27 & 19.97 & 26.20 \\
\hline Malas-aghdaie & 16 & 13.12 & 0.47 & 13.60 & 2.48 & 5.41 & 0.18 & 0.12 & 16.12 & 22.64 \\
\hline Bejestoni-poostkoloft-malasi & 16 & 13.07 & 1.02 & 14.10 & 1.68 & 4.80 & 0.42 & 0.64 & 19.67 & 26.12 \\
\hline Anbari-danehghermez & 16 & 13.20 & 1.22 & 14.42 & 1.94 & 4.34 & 0.28 & 0.72 & 18.67 & 28.74 \\
\hline Malas-gardanboland & 16 & 12.75 & 1.60 & 14.36 & 2.4 & 4.27 & 0.12 & 0.60 & 14.32 & 22.13 \\
\hline Bejestoni-torsh & 16 & 12.63 & 1.3 & 13.92 & 2.44 & 3.67 & 0.22 & 0.85 & 13.45 & 20.65 \\
\hline Dadashi-peivandie & 16 & 12.58 & 1.48 & 14.06 & 2.24 & 3.76 & 0.36 & 0.82 & 19.30 & 28.31 \\
\hline Goltorsh-mamooli & 16 & 13.27 & 1.44 & 14.72 & 1.45 & 4.31 & 0.59 & 0.82 & 17.85 & 25.52 \\
\hline Shirin-poostnazok & 16 & 12.97 & 1.42 & 14.30 & 2.3 & 3.63 & 0.24 & 0.93 & ---- & ---- \\
\hline Shahsavar-torsh & 16 & 11.94 & 1.55 & 13.50 & 2.61 & 3.39 & 0.22 & 0.88 & ---- & ---- \\
\hline Malas & 16 & 11.96 & 1.86 & 13.83 & 2.3 & 4.40 & 0.37 & 0.47 & 13.30 & 22.45 \\
\hline Malas-khomrei & 16 & 12.29 & 1.55 & 13.84 & 2.16 & 4.29 & 0.45 & 0.55 & --- & ---- \\
\hline Golabi-hastehdorosht & 16 & 12.5 & 0.44 & 12.94 & 3.05 & 4.80 & 0.11 & 0.00 & ---- & ---- \\
\hline Bazri-morst & 16 & 12.41 & 0.46 & 13.05 & 2.94 & 5.00 & 0.00 & 0.00 & --- & --- \\
\hline Khosh-poostkolft & 16 & 13.23 & 0.35 & 13.58 & 2.7 & 5.35 & 0.00 & 0.00 & 14.00 & 20.00 \\
\hline Jangli-poostghermez & 16 & 11.07 & 0.92 & 11.99 & 4.38 & 3.23 & 0.00 & 0.00 & --- & ---- \\
\hline Malas-pishva & 16 & 12.31 & 0.18 & 12.49 & 2.68 & 5.31 & 0.00 & 0.00 & --- & --- \\
\hline Shahsavar-shirin & 16 & 12.66 & 0.5 & 13.16 & 2.66 & 5.25 & 0.16 & 0.00 & 17.73 & 27.71 \\
\hline Malas-poostghermez & 16 & 10.52 & 0.89 & 11.42 & 2.94 & 4.15 & 1.57 & 0.00 & 25.57 & 35.00 \\
\hline Abdandan & 16 & 11.3 & 1.25 & 12.55 & 2.95 & 4.65 & 0.70 & 0.00 & 18.12 & 24.00 \\
\hline Malas-nahook & 16 & 10.66 & 0.14 & 10.80 & 2.23 & 4.33 & 2.95 & 0.00 & ---- & ---- \\
\hline
\end{tabular}

Abbreviation: $\mathrm{TX}=$ Mean number of terminal chiasmata, $\mathrm{IX}=$ Mean number of intercalary chiasmata, $\mathrm{TOX}=$ Mean number of total chiasmata, $\mathrm{RB}=\mathrm{Mean}$ number of ring bivalents, $\mathrm{RD}=$ Mean number of rod bivalents, I= Mean number of univalents, IV= Mean number of quadrivalents, SP1= Size of normal (reduced) pollen grains, SP2 = Size of unreduced pollen grains.

segregation occurred during the anaphase and telophase stages, some amount of irregularities occurred, such as chromosome stickiness and the formation of laggard chromosomes (Fig. $2, \mathrm{e})$ and micronuclei. Chromosome stickiness and late separation was observed in some of the cultivars (Table 4). Sticky chromosomes were observed from early stages of prophase and continued to the final stages of meiosis. The highest value of anaphase I laggards occurred in Malas-aghdaei (6.67\%) and the lowest value occurred in Anbari-danehghermez (0.87\%).

An interesting observation was the occurrence of multipolar cells and unreduced pollen grains in some of the cultivars studied (Table 4., Fig. 2, g). The size of normal (reduced) pollen grains ranged from $13.30 \mu \mathrm{m}$ in the cultivar Malas Zavareh, to $25.57 \mu \mathrm{m}$ in the cultivar Malas- poostghermez Esfahan, while the size of larger (potential unreduced) pollen grains ranged from $20.00 \mu \mathrm{m}$ in the cultivar Khosh-poostkolft Share-Babak to $35.00 \mu \mathrm{m}$ in the cultivar Malas- poostghermez Esfahan (Table 2). T-test analysis showed a significant difference between these pollen grain sizes $(t=31.76, p<0.01)$.

PCA analysis (data not shown), based on both geographical and cytological data, showed that the first 3 components comprise about $80 \%$ of total variance. In the first component, with about $34 \%$ of total variation, altitude showed the highest positive correlation with this component $(\mathrm{r}=0.58)$, while longitude showed a negative correlation $(\mathrm{r}=-0.69)$. Moreover, intercalary and total chiasmata along with the number of quadrivalents were important cytological characters of this component $(r>0.75)$.

In the second component, with about $28 \%$ of total variation, rainfall had high negative correlation $(r=-0.73)$ with the component, while elevation had a positive correlation $(r=0.65)$. Cytological features like terminal chiasmata $(r=0.66)$ and the number of rod bivalents $(r=-0.79)$ are important characters of this component.

\section{B-chromosomes}

The occurrence of 0-5 B-chromosomes was observed in some of the cultivars (Table 5). T-test analysis of chiasma frequency and chromosome pairing between the cells with B-chromosomes and those devoid of Bs showed a significant reduction in rod bivalents in the cultivars Atabaki Jahrom and Dadashipeivandie Ashkezar, while a significant increase in the mean values of quadrivalents and univalents occurred in the cultivars Bejestoni-poostkoloft and Shirin-poostnazok, respectively. Similarly a significant increase in the mean value of the intercalary chiasmata occurred in the cultivar Bejestoni torsh Khazar. 


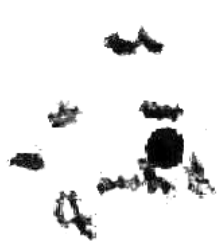

A

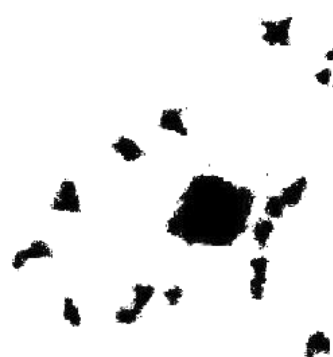

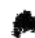

B
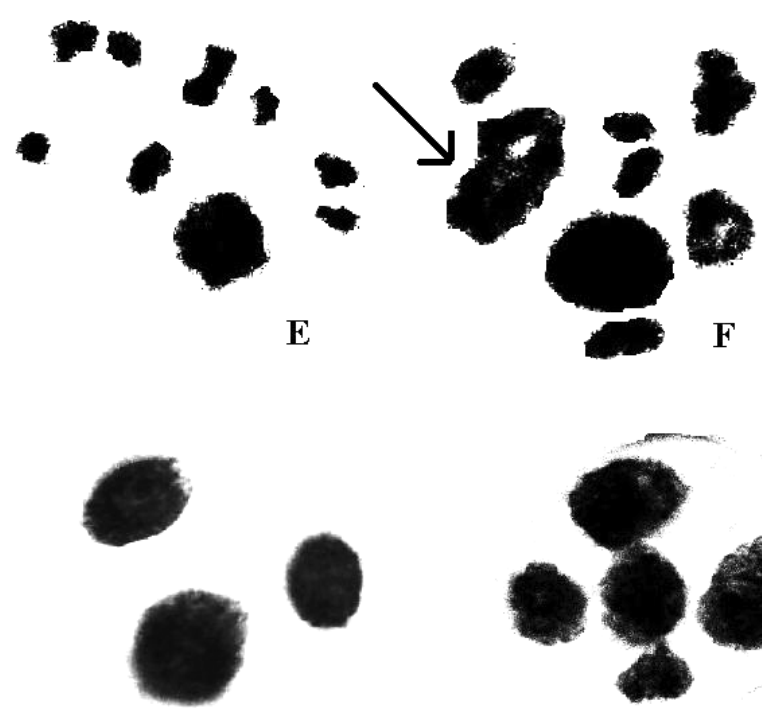

I

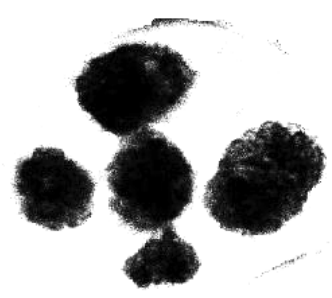

J

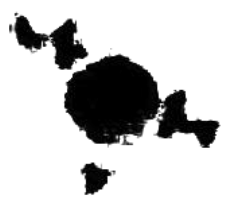

C

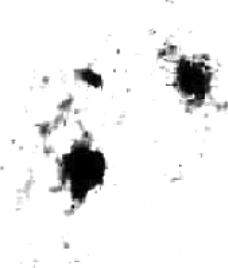

$\mathbf{G}$
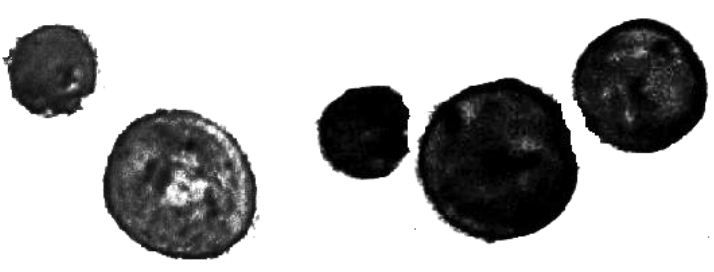

K

L

Figure 2. Representative meiotic cells in pomegranate cultivars. A and B= metaphase I cells in the Dadashipeivandie cultivar showing $2 \mathrm{n}=16$ and unreduced chromosome number $(2 n=32)$. $C=$ metaphase I cells in the Shirin-poostnazok cultivar showing $2 n=16$. $D=$ Metaphase I cells in the Anbari cultivar showing $2 n=16$ and B-chromosome (arrow). $\mathrm{E}=$ Metaphase I cells in the Goltorsh-mamooli cultivar showing $2 \mathrm{n}=16$. $\mathrm{F}=$ Metaphase I cells in the Goltorsh-mamooli cultivar showing quadrivalent (arrow). $\mathrm{G}=$ Anaphase I laggard chromosome in the Malas pishva cultivar. $\mathrm{H}=$ Tripolar cell in the Malas-aghdaei cultivar. I = Tripolar cell in the Abdandan cultivar. J = Multipolar cell in the Malas-Zavareh cultivar. K and L = Unreduced pollen grain (larger sized pollen grain) in the Dadashipeivandie and Gardanboland cultivars. Scale bar $=10 \mu \mathrm{m}$.

Comparison of the B-chromosomes effects in the cultivars studied and our earlier report (Table 5) indicates different effects of Bs. In some of the cultivars, significant increase in total chiasmata occurs while in some others, significant reduction in intercalary chiasmata occurs due to presence of B-chromosomes (Fig. 3). The same holds true for the mean value of ring and rod bivalents (Fig. 4), while in case of quadrivalents a significant increase occurs in most of the pomegranate cultivars (Fig. 5).

\section{Grouping of the cultivars}

For grouping of the cultivars, meiotic characteristics of 21 cultivars studied here were combined with the data obtained from 20 cultivars studied earlier (Table 4). UPGMA and NJ tree of the cultivars produced a similar result with higher co- phenetic correlation ( $\mathrm{r}=0.94$ ), which is discussed here (Fig. 6).

In general, 5 major clusters formed. The first major cluster consists of two sub-clusters. The cultivars Neitalkhi, Malashirin2 and Bihasteh form the first sub-cluster, while 11 cultivars (namely Dadashipoostkoloft, Shahitorsh, Alaktorsh2, Golnar, Malastorsh2, Torshpoostkoloft, Ghermeznarshirin, Malastoghi, Alaktorsh, Malastorsh, Anar-seyah) form the second sub-cluster.

The second major cluster contains Malasshahsavar2, Redki and Torshnar, while the third major cluster contains two sub-clusters. Seventeen cultivars form this major cluster and 7 cultivars namely, Malasshirin, Malas-poostghermez, Jangali, Abdandan, Malas-nahook and Golmagasi comprise the fourth major cluster. The cultivar Malasshahsavar1 alone forms the fifth cluster. 
Table 3. Pearson coefficient of correlation between geographical parameters and meiotic characters.

\begin{tabular}{|c|c|c|c|c|c|c|c|c|c|c|c|c|}
\hline & & $\mathrm{R}$ & E & $\mathrm{TX}$ & IX & TOX & RD & RB & IV & I & A & $\mathrm{L}$ \\
\hline \multirow[t]{3}{*}{$\mathrm{R}$} & Pearson Correlation & 1.000 & $-.519^{*}$ & -.185 & .048 & -.133 & $.484^{*}$ & $-.440^{*}$ & .043 & -.198 & $.528^{*}$ & -.407 \\
\hline & Sig. (2-tailed) & . & .016 & .423 & .837 & .566 & .026 & .046 & .854 & .389 & .014 & .067 \\
\hline & $\mathrm{N}$ & 21 & 21 & 21 & 21 & 21 & 21 & 21 & 21 & 21 & 21 & 21 \\
\hline \multirow[t]{3}{*}{$\mathrm{E}$} & Pearson Correlation & $-.519^{*}$ & 1.000 & .173 & .025 & .162 & -.341 & .389 & -.019 & .066 & -.236 & $.496^{*}$ \\
\hline & Sig. (2-tailed) & .016 & . & .453 & .913 & .483 & .131 & .081 & .935 & .778 & .303 & .022 \\
\hline & $\mathrm{N}$ & 21 & 21 & 21 & 21 & 21 & 21 & 21 & 21 & 21 & 21 & 21 \\
\hline \multirow[t]{3}{*}{$\mathrm{TX}$} & Pearson Correlation & -.185 & .173 & 1.000 & .039 & $.848^{*}$ & $-.525^{\star}$ & .348 & .428 & $-.634^{*}$ & -.011 & -.048 \\
\hline & Sig. (2-tailed) & .423 & .453 & . & .865 & .000 & .015 & .122 & .053 & .002 & .961 & .836 \\
\hline & $\mathrm{N}$ & 21 & 21 & 21 & 21 & 21 & 21 & 21 & 21 & 21 & 21 & 21 \\
\hline \multirow[t]{3}{*}{ IX } & Pearson Correlation & .048 & .025 & .039 & 1.000 & $.561^{*}$ & -.284 & $-.635^{\star}$ & $.759^{*}$ & -.161 & .368 & -.422 \\
\hline & Sig. (2-tailed) & .837 & .913 & .865 & . & .008 & .212 & .002 & .000 & .487 & .101 & .057 \\
\hline & $\mathrm{N}$ & 21 & 21 & 21 & 21 & 21 & 21 & 21 & 21 & 21 & 21 & 21 \\
\hline \multirow[t]{3}{*}{ TOX } & Pearson Correlation & -.133 & .162 & $.848^{*}$ & $.561^{*}$ & 1.000 & $-.582^{\star}$ & -.040 & $.749^{*}$ & $-.616^{*}$ & .179 & -.260 \\
\hline & Sig. (2-tailed) & .566 & .483 & .000 & .008 & . & .006 & .865 & .000 & .003 & .438 & .256 \\
\hline & $\mathrm{N}$ & 21 & 21 & 21 & 21 & 21 & 21 & 21 & 21 & 21 & 21 & 21 \\
\hline \multirow[t]{3}{*}{$\mathrm{RD}$} & Pearson Correlation & .484 & -.341 & $-.525^{\star}$ & -.284 & $-.582^{\star}$ & 1.000 & -.155 & $-.603^{*}$ & -.177 & .248 & -.222 \\
\hline & Sig. (2-tailed) & .026 & .131 & .015 & .212 & .006 & . & .503 & .004 & .444 & .279 & .333 \\
\hline & $\mathrm{N}$ & 21 & 21 & 21 & 21 & 21 & 21 & 21 & 21 & 21 & 21 & 21 \\
\hline \multirow[t]{3}{*}{$\mathrm{RB}$} & Pearson Correlation & -.440 & .389 & .348 & $-.635^{\star}$ & -.040 & -.155 & 1.000 & $-.575^{\star}$ & -.124 & -.302 & .466 \\
\hline & Sig. (2-tailed) & .046 & .081 & .122 & .002 & .865 & .503 & . & .006 & .591 & .183 & .033 \\
\hline & $\mathrm{N}$ & 21 & 21 & 21 & 21 & 21 & 21 & 21 & 21 & 21 & 21 & 21 \\
\hline \multirow[t]{3}{*}{ IV } & Pearson Correlation & .043 & -.019 & .428 & $.759^{*}$ & $.749^{*}$ & $-.603^{\star}$ & $-.575^{\star}$ & 1.000 & -.182 & .244 & -.376 \\
\hline & Sig. (2-tailed) & .854 & .935 & .053 & .000 & .000 & .004 & .006 & . & .430 & .286 & .093 \\
\hline & $\mathrm{N}$ & 21 & 21 & 21 & 21 & 21 & 21 & 21 & 21 & 21 & 21 & 21 \\
\hline \multirow[t]{3}{*}{ I } & Pearson Correlation & -.198 & .066 & $-.634^{\star}$ & -.161 & $-.616^{\star}$ & -.177 & -.124 & -.182 & 1.000 & $-.444^{\star}$ & $.525^{\star}$ \\
\hline & Sig. (2-tailed) & .389 & .778 & .002 & .487 & .003 & .444 & .591 & .430 & . & .044 & .014 \\
\hline & $\mathrm{N}$ & 21 & 21 & 21 & 21 & 21 & 21 & 21 & 21 & 21 & 21 & 21 \\
\hline \multirow[t]{3}{*}{ A } & Pearson Correlation & $.528^{*}$ & -.236 & -.011 & .368 & .179 & .248 & -.302 & .244 & $-.444^{*}$ & 1.000 & $-.656^{*}$ \\
\hline & Sig. (2-tailed) & .014 & .303 & .961 & .101 & .438 & .279 & .183 & .286 & .044 & . & .001 \\
\hline & $\mathrm{N}$ & 21 & 21 & 21 & 21 & 21 & 21 & 21 & 21 & 21 & 21 & 21 \\
\hline \multirow[t]{3}{*}{$\mathrm{L}$} & Pearson Correlation & -.407 & $.496^{*}$ & -.048 & -.422 & -.260 & -.222 & $.466^{*}$ & -.376 & $-.525^{\star}$ & $-.656^{*}$ & 1.000 \\
\hline & Sig. (2-tailed) & .067 & .022 & .836 & .057 & .256 & .333 & .033 & .093 & .014 & .001 & . \\
\hline & $\mathrm{N}$ & 21 & 21 & 21 & 21 & 21 & 21 & 21 & 21 & 21 & 21 & 21 \\
\hline
\end{tabular}

* = Correlation is significant at the 0.05 level (2-tailed).

Abbreviations: $\mathrm{R}=$ Rain fall $(\mathrm{mm})$, E=Elevation (meter), TX=Terminal chiasmata, IX=Intercalary chiasmata, TOX=Total chiasmata, $\mathrm{RD}=\mathrm{Rod}$ bivalents, $\mathrm{RB}=\mathrm{Ring}$ bivalents, $\mathrm{IV}=$ Quadrivalents, $\mathrm{I}=$ Univalents, $\mathrm{A}=$ Altitude and $\mathrm{L}=$ Longitude. 
Table 4. Meiotic abnormalities in pomegranate cultivars.

\begin{tabular}{lcccccccccc}
\hline & M1 & A1 & T1 & CMIX & LA1 & A1B & T & P & UP \\
\hline Atabaki-hafre & 2.17 & 3.64 & 4.06 & 5.70 & 6.36 & 0.00 & 11.40 & 0.87 & 8.50 \\
Malas-aghdaie & 9.00 & 8.33 & 4.28 & 2.85 & 6.67 & 3.33 & 3.79 & 1.26 & 9.20 \\
Bejestoni-poostkoloft-malasi & 3.30 & 0.00 & 4.70 & 4.00 & 2.85 & 2.85 & 6.47 & 0.00 & 4.60 \\
Anbari-danehghermez & 5.45 & 0.00 & 1.25 & 6.25 & 1.33 & 0.00 & 3.33 & 0.00 & 3.60 \\
Malas-gardanboland & 8.33 & 3.08 & 2.66 & 7.50 & 6.15 & 0.00 & 12.10 & 1.72 & 10.30 \\
Bejestoni-torsh & 7.00 & 5.33 & 3.80 & 1.90 & 0.00 & 0.00 & 4.75 & 0.00 & 6.20 \\
Dadashi-peivandie & 9.41 & 6.66 & 1.54 & 7.70 & 0.00 & 2.22 & 8.33 & 0.00 & 5.80 \\
Goltorsh-mamooli & 7.70 & 4.28 & 1.33 & 0.00 & 4.28 & 1.43 & 5.00 & 0.00 & 4.10 \\
Shirin-poostnazok & 1.51 & 2.73 & 0.00 & 2.22 & 1.82 & 3.64 & 0.00 & 0.00 & 0.00 \\
Shahvar-torsh & 1.43 & 0.00 & 0.00 & 0.83 & 0.00 & 0.00 & 0.00 & 0.00 & 0.00 \\
Malas & 3.33 & 3.80 & 7.27 & 3.64 & 2.53 & 1.27 & 7.25 & 4.03 & 6.50 \\
\hline Golabi-hastehdorosht & & & & & & & &
\end{tabular}

Abbreviations: $\mathrm{M} 1=$ Chromosome stickiness in metaphase I, A1 = Chromosome stickiness in anaphase I, T1 = Laggard chromosomes in telophase I, CMIX = Cytomixis, Laggard chromosomes in anaphase I, A1B $=$ Chromosome bridge in anaphase $\mathrm{I}, \mathrm{T}=$ Abnormal tetrads, $\mathrm{P}=$ Pentad formation, $\mathrm{UP}=\mathrm{Unreduced}$ pollen grain. (All values are in percentage).

Table 5. Cytogenetic characteristics in the cells with B-chromosomes and the cells devoid of Bs. (The first 6 cultivars are from the present work and the rest from our previous study).

\begin{tabular}{|c|c|c|c|c|c|c|c|c|c|}
\hline Cultivar & & $\mathrm{TX}$ & IX & TOX & $\mathrm{RB}$ & ROB & QU & I & B-chromosomes \\
\hline \multirow{2}{*}{ 1. Atabaki-hafre } & $+\mathrm{B}$ & 13.57 & $0.71^{*}$ & 14.28 & 3.86 & $1.43^{*}$ & $1.14^{*}$ & 0.57 & \multirow[t]{2}{*}{$0-1$} \\
\hline & $-B$ & 13.15 & 0.17 & 13.34 & 5.02 & 2.56 & 0.12 & 0.12 & \\
\hline \multirow{2}{*}{ 2. Bejestoni-poostkoloft-malasi } & $+\mathrm{B}$ & 13.25 & 1.08 & 14.5 & 4.17 & 2.17 & 0.83 & $0.083^{*}$ & \multirow{2}{*}{$0-3$} \\
\hline & $-B$ & 13 & 1 & 13.94 & 6.65 & 1.74 & 0.32 & 0.55 & \\
\hline \multirow{2}{*}{ 3. Anbari-danehghermez } & $+\mathrm{B}$ & 12.54 & 0.84 & 13.38 & 3.31 & 2.46 & 1.07 & $0.07^{*}$ & \multirow{2}{*}{$0-3$} \\
\hline & $-B$ & 13.43 & 1.35 & 14.78 & 4.7 & 1.76 & 0.59 & 0.48 & \\
\hline \multirow{2}{*}{ 4. Bejestoni-torsh } & $+\mathrm{B}$ & 12.56 & $1.56^{*}$ & 14.11 & 3.89 & 2.33 & 0.78 & 0.22 & \multirow{2}{*}{$0-5$} \\
\hline & $-B$ & 12.67 & 1.17 & 13.83 & 3.56 & 2.5 & 0.89 & 0.22 & \\
\hline \multirow{2}{*}{ 5. Dadashi-Peivandie } & $+B$ & 13.30 & 1.40 & 14.70 & 3.70 & $1.70^{*}$ & 1.10 & $0.20^{*}$ & \multirow[t]{2}{*}{$0-3$} \\
\hline & $-B$ & 12.40 & 1.50 & 13.90 & 3.87 & 2.37 & 0.75 & 0.40 & \\
\hline \multirow{2}{*}{ 6. Shirin-poostnazok } & $+\mathrm{B}$ & 12.8 & 1.00 & 13.80 & 3.60 & 1.80 & 1.00 & 0.60 & \multirow{2}{*}{$0-3$} \\
\hline & $-B$ & 13.00 & 1.50 & 14.50 & 3.64 & 2.39 & 0.93 & 0.18 & \\
\hline \multirow{2}{*}{ 7. Neitalkhi } & $+\mathrm{B}$ & 15 & $0.66^{*}$ & 15.66 & 7 & 1 & 0 & 0 & \multirow{2}{*}{$0-2$} \\
\hline & $-B$ & 14.8 & 0.35 & 15.15 & 6.84 & 0.98 & 0.04 & 0.15 & \\
\hline \multirow{2}{*}{ 8. Ghermeznarshirin } & $+\mathrm{B}$ & 12.75 & 0.5 & 13.25 & 5.12 & $2.78^{*}$ & 0 & 0.25 & \multirow{2}{*}{$0-5$} \\
\hline & $-B$ & 13.85 & 0.42 & 14.27 & $6.44^{*}$ & 1.28 & 0 & 0.71 & \\
\hline \multirow{2}{*}{ 9. Malas-Shahsavar1 } & $+\mathrm{B}$ & 14.44 & 0.11 & 14.55 & 6.66 & 1.1 & 0 & 0.44 & \multirow{2}{*}{$0-2$} \\
\hline & $-B$ & 13.45 & 0.24 & 13.58 & 6.66 & 1.7 & 0 & 0.52 & \\
\hline \multirow{2}{*}{ 10. Dadashipoostkoloft } & $+\mathrm{B}$ & 13.6 & 0 & 13.6 & 5.6 & $2.40^{*}$ & 0 & 0.44 & \multirow{2}{*}{$0-2$} \\
\hline & $-B$ & 13.63 & 0.12 & 13.75 & 6 & 1.55 & 0.03 & 0.73 & \\
\hline \multirow{2}{*}{ 11. Golnar } & $+\mathrm{B}$ & 13.6 & 0 & 13.6 & 6 & 1.6 & 0 & 0.8 & \multirow{2}{*}{$0-3$} \\
\hline & $-B$ & 13.45 & 0.22 & 13.67 & 6 & 1.45 & 0.03 & 0.97 & \\
\hline \multirow{2}{*}{ 12. Shahitorsh } & $+\mathrm{B}$ & 13.6 & 0 & 13.6 & 5.8 & $2.00^{*}$ & 0 & 0.4 & \multirow{2}{*}{$0-1$} \\
\hline & $-B$ & 14.4 & 0.1 & $14.50^{*}$ & 6.6 & 1.1 & 0 & 0.4 & \\
\hline \multirow{2}{*}{ 13. Torshpoostkoloft } & $+\mathrm{B}$ & 13.4 & 0.57 & 13.97 & 6.3 & 1.14 & 0 & 1.14 & \multirow{2}{*}{$0-2$} \\
\hline & $-B$ & 13.74 & 0.54 & 14.28 & 6.54 & 1.15 & 0 & 0.61 & \\
\hline \multirow{2}{*}{ 14. Malastoghi } & $+\mathrm{B}$ & 13.22 & 0.66 & 13.88 & 5.78 & 1.9 & 0 & 0.66 & \multirow{2}{*}{$0-3$} \\
\hline & $-B$ & 13.37 & 0.43 & 13.8 & 6 & 1.52 & 0.03 & 0.8 & \\
\hline
\end{tabular}


Table 5. Continuação.

\begin{tabular}{|c|c|c|c|c|c|c|c|c|c|}
\hline Cultivar & & $\mathrm{TX}$ & IX & TOX & $\mathrm{RB}$ & ROB & QU & I & B-chromosomes \\
\hline \multirow{2}{*}{ 15. Malastorsh } & $+\mathrm{B}$ & 13.1 & 1.31 & 14.41 & 6 & $1.53^{*}$ & 0 & 0.92 & \multirow{2}{*}{$0-4$} \\
\hline & $-B$ & 13.75 & 1.35 & 15.1 & 6.52 & 1 & 0 & 0.72 & \\
\hline \multirow{2}{*}{ 16. Malasshirin } & $+\mathrm{B}$ & 10.67 & 1 & 11.67 & 3.83 & 3.66 & 0 & 1 & \multirow{2}{*}{$0-2$} \\
\hline & $-B$ & 9.8 & 1.44 & 11.24 & 3.94 & 3 & 0 & 1.64 & \\
\hline \multirow{2}{*}{ 17. Alaktorsh } & $+\mathrm{B}$ & 13 & 1.1 & 14.1 & 5.5 & 2.2 & 0 & 0.6 & \multirow{2}{*}{$0-3$} \\
\hline & $-B$ & 12.66 & 1.63 & 14.29 & 5.44 & 1.89 & 0 & 0.78 & \\
\hline \multirow{2}{*}{ 18. Berit } & $+\mathrm{B}$ & 10.83 & 1.42 & 12.25 & 4.75 & 2.5 & 0.25 & 0.93 & \multirow{2}{*}{$0-4$} \\
\hline & $-B$ & 11.9 & 1 & 12.9 & 4.63 & 2.84 & 0.1 & 0.63 & \\
\hline \multirow{2}{*}{ 19. Golmagasi } & $+\mathrm{B}$ & 10.5 & $5.50^{*}$ & $16.00^{*}$ & 5.5 & 2.5 & 0 & 1 & \multirow{2}{*}{$0-2$} \\
\hline & $-B$ & 10.85 & 2.6 & 13.45 & 5.3 & 1.23 & 0 & $2.60^{*}$ & \\
\hline \multirow{2}{*}{ 20. Anar-seyah } & $+\mathrm{B}$ & 12.8 & 1 & 13.8 & 5.8 & 0.8 & 0.2 & 1.2 & \multirow{2}{*}{$0-3$} \\
\hline & $-B$ & 14.14 & 1 & $15.14^{*}$ & 6.85 & 0.6 & 0 & 1.1 & \\
\hline \multirow{2}{*}{ 21. Malas-Shahsavar2 } & $+\mathrm{B}$ & 13.44 & $2.67^{*}$ & $16.44^{*}$ & 6.66 & 1.33 & 0 & 0 & \multirow{2}{*}{$0-2$} \\
\hline & $-B$ & 13.4 & 1.93 & 15.33 & 6.27 & 1.4 & 0 & $0.55^{\star}$ & \\
\hline \multirow{2}{*}{ 22. Redki } & $+\mathrm{B}$ & 13.5 & 2 & 15.5 & 6.5 & 1.5 & 0 & 0 & \multirow{2}{*}{$0-1$} \\
\hline & $-B$ & 14.4 & 1.6 & 16 & 6.75 & 1 & 0 & $0.50^{*}$ & \\
\hline
\end{tabular}

${ }^{*}=$ Significant at $5 \%$ level.

The result of UPGMA clustering based on the origin of cultivars (Fig. 7) shows no affinity between the cultivars from similar regions. For example, although most of the cultivars growing in Saveh city (Markazi province) are close to each other in the first major cluster, cultivar Malas-shirin from the same geographical region is in the third major cluster far from the others. Similarly, the cultivars growing in Yazd province (Yazd, Bafgh and Taft cities), although they show some similarities with each other, are distributed in 3 different clusters. Moreover, the cultivars growing in Shabestar (East-Azerbaijan province) are far from each other in 2 close-by major clusters. This is further supported by the PCoA plot showing that (Fig. 8) all geographical areas from which pomegranate cultivars have been investigated are distributed in different axes of the PCoA plot. Only the cultivars growing in Tehran and Semnan provinces (code 5 and 7 respectively in Fig. 8) show limited distribution in this plot.

\section{Discussion}

\section{Chromosome pairing and chiasma frequency}

The values obtained for chiasma frequency and chromosome pairing here is in agreement with the range of values obtained in other culivars studied (Sheidai et al. 2005; 2008). Pearson coefficient of correlation determined between pollen fertility and cytogenetic characters studied revealed a positive significant correlation between total chiasmata and pollen fertility indicating that with an increase in chiasma number increase in pollen fertility occurs.

The pomegranate plant is diploid and is expected to form merely bivalents and univalents in metaphase I of meiosis. As we described earlier, some amount of quadrivalents were formed in the cultivars studied. A possible reason for quadrivalent formation may be the occurrence of translocation between two pairs of chromosomes. Heterozygote translocations may form new linkage groups and bring about new genetic changes in the genome in which they occur.

The regular occurrence of univalents in the cultivars studied may be due to small size of chromosomes and early terminalization of chiasmata in them. Such univalents may be one of the reasons for the formation of laggard chromosomes observed in the cultivars studied.

The frequency and distribution of chiasma are under genetic control (Rees \& Jones 1977), and the heritable adjustment in the frequency and distribution of chiasma and recombination, as well as their effects on the variability of progenies and populations, is established in both experimental and natural populations (Rees \& Jones 1977). Therefore, the presence of a significant difference in chiasma frequency and distribution as well as ring and rod bivalents among the cultivars grown under uniform conditions may indicate genomic differences (Sheidai et al. 2002).

\section{Unreduced pollen grains}

The cultivars studied differ in their meiotic abnormalities including laggard and micronuclei chromosomes and potential of unreduced pollen grain formation. Therefore, these differences may be used in planning cultivar selection and hybridization.

A numerically unreduced diploid $(2 n)$ gamete is a meiotic product which bears the sporophytic rather than the gametophytic chromosome number. Such gametes result from abnormalities during either microsporogenesis $(2 n$ pollen) or megasporogenesis ( $2 n$ eggs). Unreduced gametes are known to produce individuals with higher ploidy level 


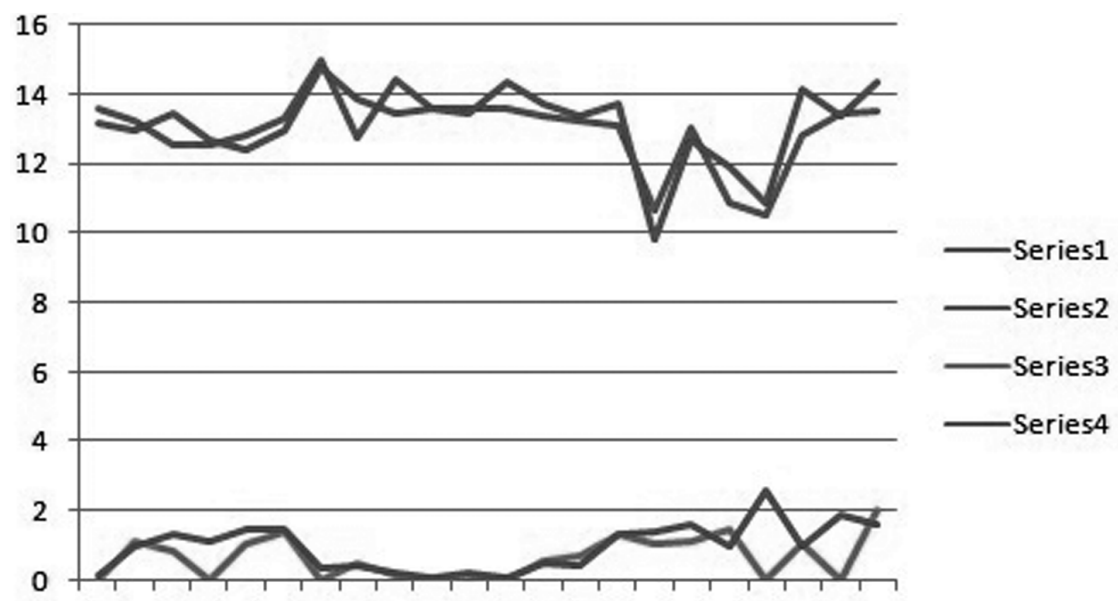

12334556778910111213141516171819202122

Figure 3. Effect of B-chromosomes on total (up) and intercalary chiasmata (down). Series 1 and $3=$ With B-chromosomes, series 2 and $4=$ devoid of B-chromosomes.

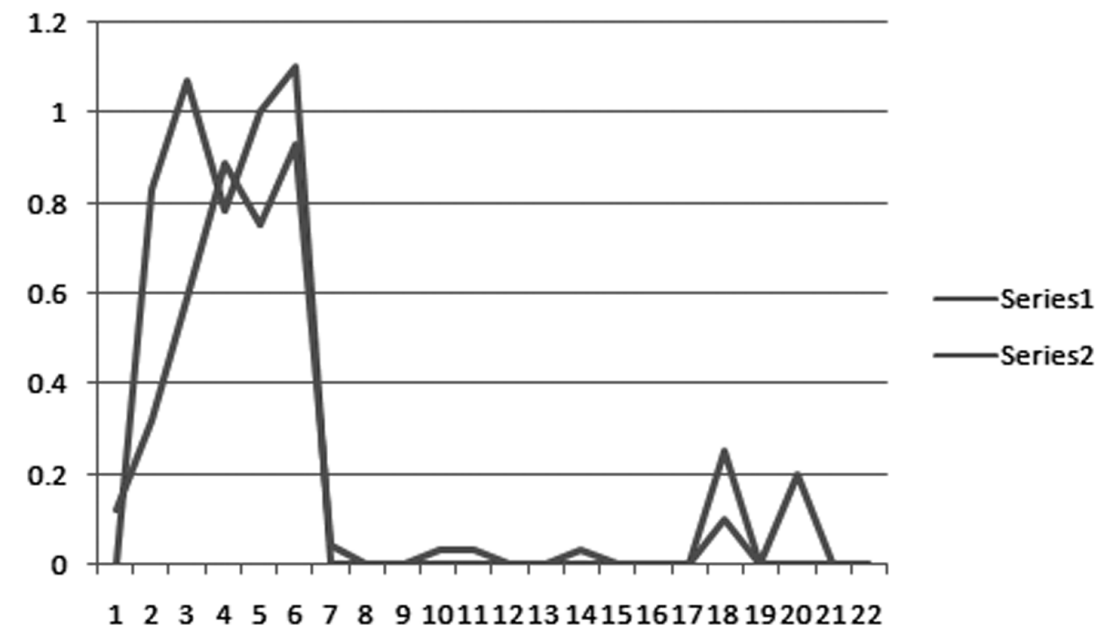

Figure 4. Effect of B-chromosomes on mean value of quadrivalents. Series 1 = With B-chromosomes, series $2=$ devoid of B-chromosomes.

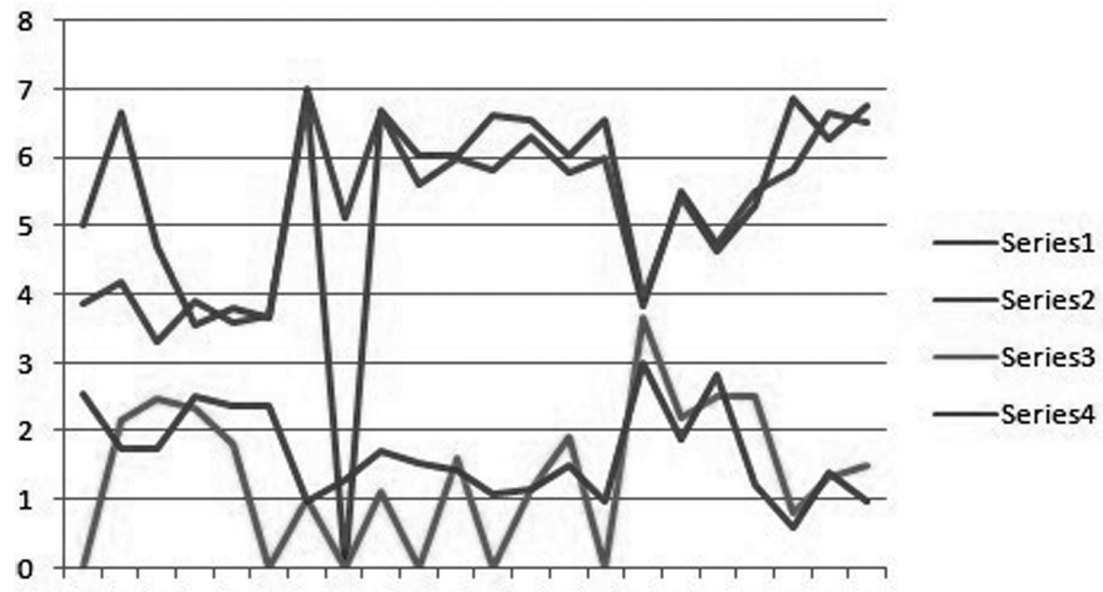

125345567788910111213141516171819202122

Figure 5. Effect of B-chromosomes on ring (up) and rod bivalents (down). Series 1 and $3=$ With B-chromosomes, series 2 and $4=$ devoid of B-chromosomes. 


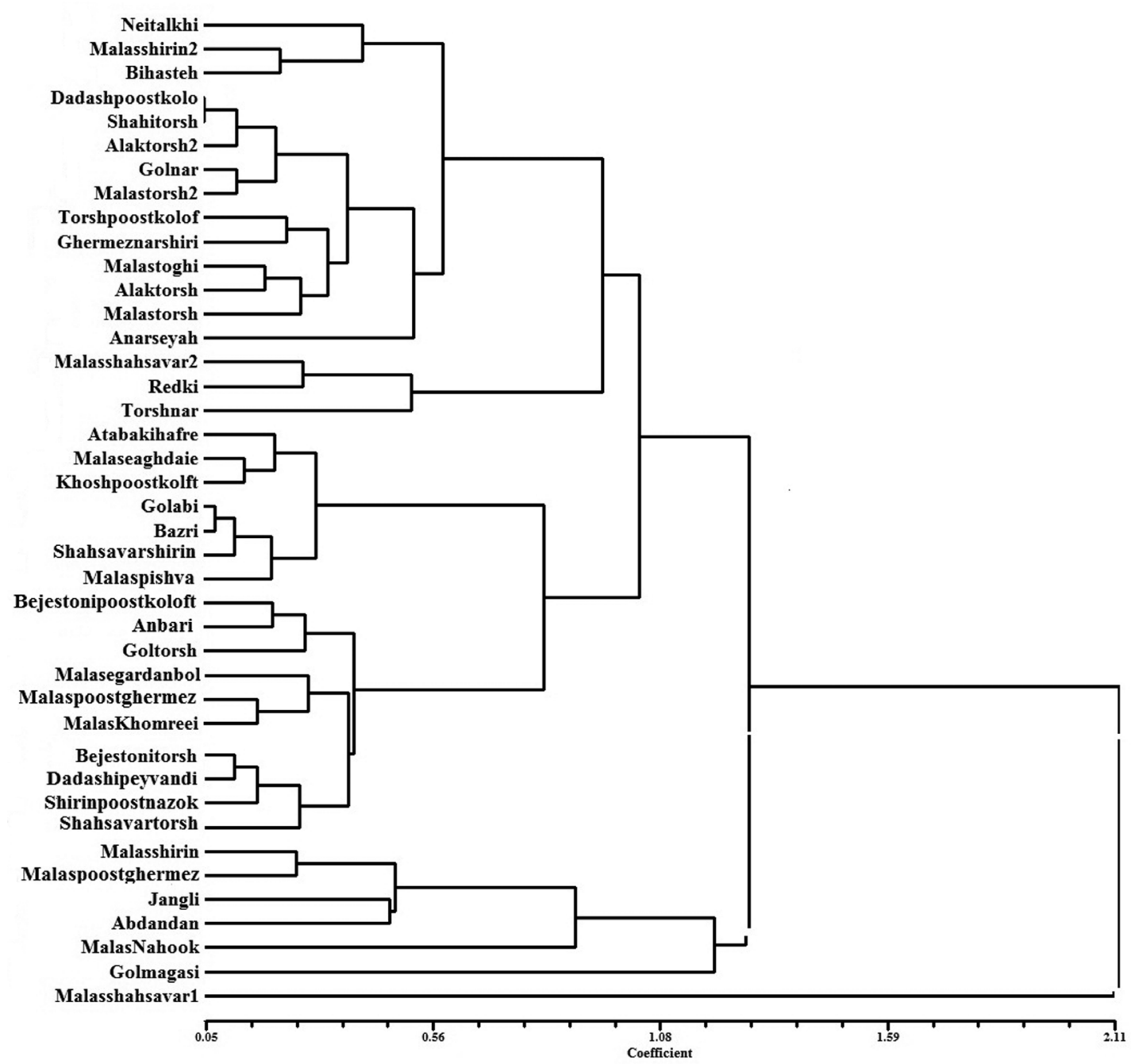

Figure 6. UPGMA cluster based on cytological characters in 41 pomegranate cultivars.

through a process known as sexual polyploidization (Villeux 1985). Different cytological mechanisms are responsible for the production of $2 n$ gametes, including premiotic doubling of the chromosomes, omission of the first and second meiotic division, post-meiotic division, abnormal spindle geometry, abnormal cytokinesis and desynapsis (Villeux 1985). The present study shows tripolar cell formation due to anaphase I failure as the main cytological mechanisms of unreduced pollen grain formation in the pomegranate cultivars studied.

Genetic and environmental factors as well as genomic-environmental interaction have been considered as the reason for chromosome stickiness in different plant species (Nirmala \& Rao 1996). However, Baptista-Giacomelli et al. (2000) reported a difference in the percentage of cells showing stickiness in Brazilian Avena sativa cultivars and suggested a genomic- environmental interaction as the main reason for the occurrence of chromosome stickiness; this may hold true for the Punica granatum cultivars studied.
The spindle apparatus is normally bipolar and acts as a single unit, playing a crucial role in chromosome alignment during metaphase, but its distortion or breakage may result in random sub-grouping. Spindle abnormalities due to duality of the nucleus in foreign cytoplasm and environmental causes (Nirmala \& Rao 1996), led to the production of aneuploid and polyploid/ unreduced (2n) gametes, for example, in polyploidy hybrids and derivatives of Aegilops $\times$ Triticum hybrids, amphiploid Triticineae, and amphiploids of Solanum hybrids (Villeux 1985).

The presence of giant grains has been seen as an indication of the production of $2 \mathrm{n}$ pollen (Vorsa \& Bingham 1979). Significant difference between small sized and larger sized (potential $2 \mathrm{n}$ pollen) grains was observed in the pomegranate cultivars studied.

\section{Grouping of the cultivars/geographical diversity}

Grouping of the cultivars based on meiotic data separated the pomegranate cultivars in distinct groups, indicating 


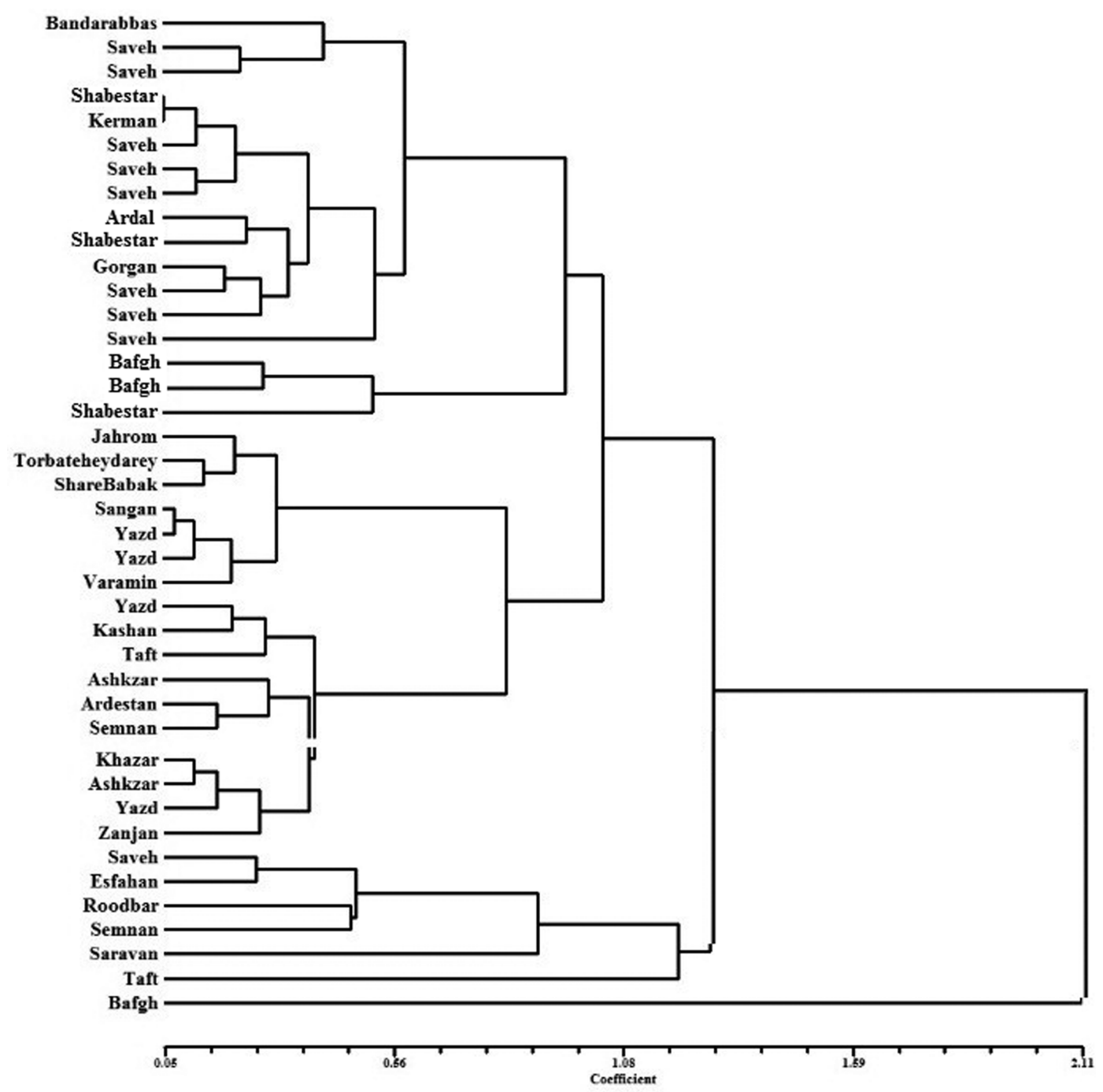

Figure 7. UPGMA dendrogram based on geography of the cultivars.

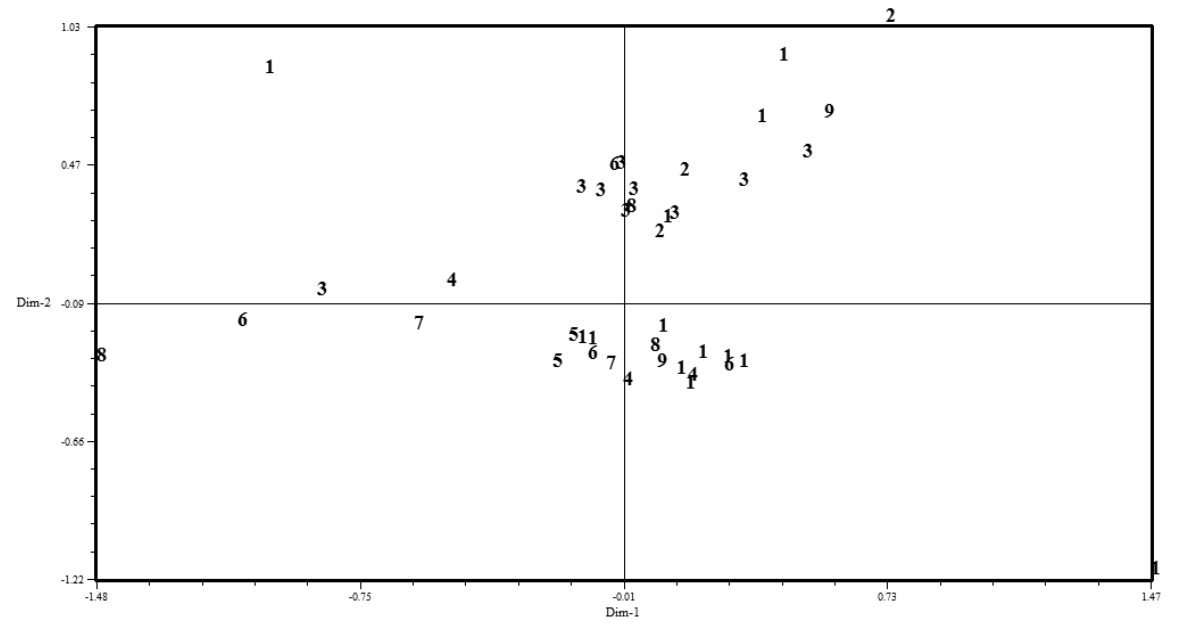

Figure 8. Cytogenetic diversity of the cultivars in different geographical regions. 1-9 are, respectively: Yazd, Shabestar, Saveh, Mazandaran, Tehran, Esfahan, Semnan, eastern Iran, and Southern Iran. 
their cytogenetic (partly genetic) differences supported by the ANOVA test. UPGMA clustering based on the origin of cultivars was performed to study if the cultivars growing in the same geographical area are related to show affinity to each other (Fig. 7). As it is evident in the dendrogram, no affinity is apparent between them. For example, the cultivars growing in Saveh city (Markazi province) are placed in the first and third major clusters. Similarly, the cultivars growing in Yazd province (Yazd, Bafgh and Taft cities), although showing some similarities with each other, are distributed in 3 different clusters. Moreover, the cultivars growing in Shabestar (East-Azerbaijan province) are placed far from each other in two close-by major clusters.

A PCoA plot was drawn to indicate the level cytogenetic variability among different geographical regions studied (Fig. 8). It is clear that all geographical areas from which pomegranate cultivars have been investigated are distributed in different axes of the PCoA plot, indicating a similar level of cytogenetic diversity.

Iran has a continental type of climate, with cold winters and hot summers prevalent across the plateau. On the plateau, the annual rainfall does not exceed $30 \mathrm{~cm}$ (12 in), with the deserts and the Persian Gulf littoral receiving less than $13 \mathrm{~cm}$ (5 in). These cultivars are grown from the far northern region to the far southern part of the country and also from the eastern and western parts of Iran (Fig. 1 ), which have different environmental conditions, such as climate, rainfall, altitude and latitude (Table 1). Therefore, pomegranate cultivars are widely adapted to potentially adverse environmental conditions and for a country like Iran, with high habitat diversity, are suitable plant crops to focus on. We did not find any particular geographic region in the country that had more genetic diversity in the cultivars, although some hints about limitation in genetic diversity were observed for the cultivars collected from two provinces of Tehran and Semnan (code 5 and 7 respectively in Fig. 8), which showed limited distribution in the PCoA plot. This limited genetic diversity may be due to a lower number of the cultivars studied from these two regions or due to an actual lower genetic variation available in them. The cultivars studied in these two regions also lack B-chromosomes (will be discussed below), while the cultivars from all the other regions had a different number of B-chromosomes.

\section{B-chromosomes}

B-chromosomes (Bs) are accessory chromosomes reported in more than 1300 species of plants and almost 500 species of animals (Camacho et al. 2000). B-chromosomes show numerical polymorphism and when present in high numbers reduce the growth and vigor of the plants, but in low numbers the can be beneficial. One of the main effects of $\mathrm{BS}$ is the change in the chiasma frequency and distribution and chromosome association (Camacho et al. 2000). This can be directly due to the B-chromosomes or the result of their effect on the genes controlling meiosis present on the A-chromosomes (Camacho et al. 2000).

As mentioned earlier, the presence of B-chromosomes significantly changed the chiasma frequency and chromosome pairing in the cultivars studied. An increase in chiasma number may enhance genetic variation and in those cultivars with an increase in their intercalary chiasmata, the genes located in the intercalary positions of the chromosome arms also become involved in genetic recombination. This is further increased by significant increase in the mean value of quadrivalents (higher amount of heterozygote translocation), which brings about more genetic diversity in the gametes formed.

An increase in the number of ring bivalents and decrease in the number of univalents also improve the proper segregation of chromosomes in anaphase leading to higher pollen fertility in the cultivars with B-chromosomes. However, as stated before, significant reduction in the mean values of chiasma frequency and ring bivalents was also observed in some of the cultivars. Therefore the effects of B-chromosomes vary in the different Punica granatum cultivars studied, which may be due to the difference in their genetic background. This is also supported by the fact that the cultivars growing in different geographical regions of Iran have different numbers of B-chromosomes, except for the cultivars growing in Tehran and Semnan provinces that also show limited diversity in the PCoA plot presented. The result of PCoA analysis clearly showed that both geographical and cytological features contribute greatly to the diversity observed in pomegranate cultivars.

All of these findings enhance the idea of thorough germplasm collection throughout the country and also suggest we should collect as many tree samples as possible from each geographical region, which might have high genetic diversity as was found in the present work. The samples and and their genetic diversity will improve the genetic stock available for further hybridization and breeding programs.

\section{References}

Baptista-Giacomelli, F.R.; Pagliarini, M.S \& Almeida, J.L. 2000. Meiotic behavior in several Brazilian oat cultivars (Avena sativa L.). Cytologia 65: 371-378.

Behzadi-Shahrbabaki, H. 1998. Genetic diversity of pomegranate genotypes in Iran. Tehran, Nashr Amoozesh Keshavarzi.

Gill, B.; Bir, S.S. \& Bedi, Y.S. 1981. Cytological studies on woody Euphorbiaceae from North and Central India. New Botanist 8: 35-44.

Gong, X.M.; Zhang, S.M.; Song, F.S. \& Zhu, L.W. 2004. Economic characteristics of fruits in pomegranate cultivars in China. Plant Genetic Resources 5: 17-21.

Nirmala, A. \& Rao, P.N. 1996. Genesis of chromosome numerical mosaism in higher plants. The Nucleus 39: 151-175.

Podani, J. 2000. Introduction to Exploration of Multivariate Biological Data. (English Translation). Leiden, Backhuys Publishers.

Raman, V.S.; Manimekaliai, G. \& Sreerangaswamy S.R. 1971. Chromosome behavior at meiosis in Punica granatum L. Cytologia 36: 400-404. 
Rees, H. \& Jones, R.N. 1977. Chromosome Genetics. London, Edward Arnold.

Sheidai, M.; Arman, M. \& Zehzad, B. 2002. Chromosome pairing and B-chromosomes in some Aegilops species and populations of Iran. Caryologia 55(3): 261-271.

Sheidai, M.; Noormohamadi, M.; Kashani, N. \& Ahmadi, M. 2003. Cytogenetic study of some rapeseed (Brassica napus L.) cultivars and their hybrids. Caryologia 56(4): 387-397.

Sheidai, M. \& Noormohammadi, Z. 2005. Chromosome pairing and unreduced gamete formation in nineteen pomegranate (Punica granatum L.) cultivars. Cytologia 70: 257-265.

Sheidai, M.; Khandan, M. \& Nasre-Esfahani, Sh. 2005. Cytogenetical study of some Iranian pomegranate (Punica granatum L.) cultivars. Caryologia 58: 132-139.

Sheidai, M.; Noormohammadi, Z.; Saneghi, A. \& Shahryari, Z.H. 2007. RAPD analysis of eleven Iranian pomegranate (Punica granatum L.) cultivars. Acta Biologia Szegediensis 51: 61-64.
Sheidai, M.; Saneghi, A.; Havali-Shahreiyari, Z.; Noormohammadi, Z.; Farahanei F. \& Tabatabaei-Ardakanei, Z. 2008. RAPD and Cytogenetic study of some pomegranate (Punica granatum L.) cultivars. Caryologia 61: 68-73.

Stover, E. \& Mercure, E.W. 2007. The pomegranate: A new look at the fruit of paradise. Horticultural Science 42: 1088-1092.

Talebi-Baddaf, M.; Sharifi-Neia, B. \& Bahar, M. 2003. Analysis of genetic diversity in pomegranate cultivars of Iran, using Random Amplified Polymorphic DNA (RAPD) markers. Pp. 343-345. In: Proceedings of the Third National Congress of Biotechnology. Iran, Mashhad.

Villeux, R. 1985. Diploid and polyploid gametes in Crop Plants: Mechanisms of formation and utilization in plant breeding. In: Janick, J. (Ed.). Plant Breeding Review. Vol. 3. Wesport, Connecticut, AVI Publishing Company.

Vorsa, N. \& Bingham, E.T. 1979. Cytology of 2n pollen formation in diploid alfalfa, Medicago sativa. Canadian Journal of Genetic and Cytology 21: 525-530.

Xue, B.S.; Weng, R.F. \& Zhang, M.Z. 1992. Chromosome numbers of Shanghai plants I. Investigatio et Studium Naturae 12: 48-65. 